\title{
The prevention of child trafficking crimes and its legal reform
}

\author{
Nanci Yosepin Simbolon* and Madyasah Ablisar \\ Doctoral Program in Law, Graduate School, Universitas Sumatera Utara, Medan, \\ Indonesia
}

\begin{abstract}
The news about human trafficking especially children in Indonesia is increasing both domestically and across borders. The crime also includes in the form of labor smuggling, immigrant smuggling, slave trade, women and children. One of the most serious and very complex issues is the impact it has on and directly related to the child's fate. In 2016, the Ministry of Women Empowerment and Child Protection reported, there were 943 victims of human trafficking reported in 65 the media. Separately, the Indonesian Child Protection Commission officially identifies 307 child trafficking victims. It remains unclear whether these two processes lead to an investigation or provision of protection to victims. This research uses normative research method to find out the prevention of child trafficking crime and form of legal renewal about child trafficking. This study states that the prevention of child trafficking victims is by prevention, prosecution to traffickers, and protection measures against victims. In addition, there needs to be a renewal of criminal law which should also focus on the protection of victims of trafficking in persons so as to provide opportunities for victims to gain their rights.
\end{abstract}

\section{Introduction}

The case of child trafficking is also linked to the praxis of globalization driven by crossborder business practices, transnational corporations, and international economic and financial institutions. In this context, globalization is driven by the exploration of the business sector that continually seeks new areas for production, distribution, and markets most profitable for the process of capital and profit accumulation. The existence of likage between child trade issues. Globalization and the transnational business of globalization pressure has led to child labor and forced labor systems.

The news about human trafficking especially children in Indonesia is increasing both domestically and across borders. [1] This can be seen from various crimes committed by individuals and corporations within the borders of an increasingly diverse country. The

\footnotetext{
* Corresponding author: yosepinn@yahoo.com
} 
crimes also include among others the smuggling of labor, immigrant smuggling, slave trade, trafficking of women and children.

The trafficking of children in Indonesia has threatened the existence and dignity of humanity that endanger the future of the child.[2] Globally, child trafficking is an organized crime that extends beyond the border of the country so it is known as transnational crime. Indonesia is listed and declared as one of the countries of international child trafficking and transit, especially for the purpose of prostitution and child labor in the world.[3]

This unity of commitment to the abolition of child trafficking was known through the Palermo protocol in 2001. The deal on the abolition of child trafficking as a global issue, in line with the scope of the deal of eliminating terrorism, arm smuggling, ilegally drug trafficking and psychotropic, money laundering, smuggling people and child trafficking. Indonesia has ratified the Palermo protocol for the abolition of transnational crime.[4]

The Convention on the Rights of the Child (CRC) is one of the conventions governing matters relating to the protection of the rights of the child. Article I states that $y$ is meant by child is every human being below the law. Under this provision it is further determined that there is a requirement for the State to pay attention to all forms of violence against children.[5]

Specifically, for child trafficking, it is contained in Article 35 which states that the parties would take all appropriate national, bilateral and multilateral measures to prevent the abduction of the sale of or sale in children of welfare.

In order to increase the protection to victims of trafficking in persons, it is carried out by increasing the accessibility of services through the establishment of Integrated Service Centers at Public Hospitals owned by Central, Provincial and District/City Government as well as Central Police Hospital and Bhayangkara Hospital in the region.[6] In addition, many NGOs and community organizations established women's crisis centers, Drop In Centers, or shelters.[7]

Strengthening the commitment of the Government of the Republic of Indonesia in the elimination of trafficking in persons is reflected in Presidential Decree No. 88/2002 on the National Plan of Action on the Elimination of Trafficking of Women and Children and the Act of the Elimination of Human Trafficking National Action on Combating Trafficking in Persons 2015-2019.[8]

\section{Problem}

The problem of this research is formulated as: How is the prevention of child trafficking and its legal reform?

\section{Research methods}

In accordance with the problems above, this research material is included in qualitative research through normative juridical approach by looking at the rules, both the primary legal material (the Law on the Elimination of Crime of Trafficking in Persons, the Criminal Code) as well as secondary legal materials (textbooks, and others), and tertiary legal materials (dictionaries, encyclopedias, etc.).

\section{Discussions}

Theory of Legal Protection against children presented by Philipus M Hadjon, which focuses on legal protection in the field of child rights. According to Barda Nawawi Arief, child 
protection theory can be interpreted as an effort to protect the law against various freedom and fundamental rights of children (children rights and freedoms of children) and various interests related to the welfare of children. Child protection in general is a way of life and livelihood of the child that can guarantee its growth and development properly, spiritually, physically and socially.[9]

Legal protection is all efforts are made consciously by all individuals and government agencies, the private sector aimed at seeking security, control and compliance welfare in accordance with the rights that exist as stipulated in Act Number 39 of 1999 concerning Human Rights. Every Indonesian child is a valuable asset of the nation, the future generation and human resources of Indonesia that will be the determinant of the future of the nation and state. The State is obliged to create a sense of security and provide legal protection to every Indonesian child in order for them to grow and develop properly and participate in development. Legal protection of children is the legal protection of various fundamental rights and freedoms of children and various interests related to the welfare of children.[10]

Child Protection is all activities to guarantee and protect children and their rights in order to live, grow, develop and participate optimally in accordance with human dignity and values and to be protected from violence and discrimination. Child protection is a joint activity aimed at securing the security, procurement and fulfillment of the spiritual and physical well-being of the child in accordance with his or her interests and rights.[11]

Child protection is a manifestation of justice in a society. Law is a guarantee for child protection activities. Legal certainty should be endeavored for the sake of continuity of child protection activities and prevent misconduct that brings unintended negative consequences in the implementation of child protection.

Human trafficking is an act of recruitment, transportation, shelter, transfer, transfer or acceptance of persons with threats of violence, the use of harassment, abduction, capture, falsification, fraud, abuse of power or vulnerable positions, debt bondage or paying or benefits, persons exercising control over such persons, whether committed within States or between States, for the purpose of exploitation or exploitation of persons.

Similarly, child prostitution is not always a victim of trafficking, because to be categorized as a trafficking victim the child must be recruited by a network of syndicates, or the child is deceived with incorrect information about the work to be performed.[12] Child trafficking may be for various purposes, including for prostitution, for pornographic objects, for forced labor, for organ transfusion, for drug traffickers, for adoption and so forth.

The anti-trafficking unit of the National Police's Criminal Investigation Unit reported 110 case investigations during 2017, this number declining compared to 2016 with 221 cases.10 Figures reported in 2016 may include cases of forced marriage and human organ trafficking. The Supreme Court reported 256 rulings, up from 119 decisions in the previous year, with a verdict of up to 7 years in prison.[13]

In 2017, the Ministry of Women Empowerment and Child Protection reported a partnership with a communications company to collect open information on 943 victims of trafficking reported in 65 print, online and broadcast media as an effort to extend the method of identifying victims. (Children, 2016) Separately, the Indonesian Child Protection 
Commission officially identifies 307 child trafficking victims.[14] It remains unclear whether these two processes led to the investigation or protection of victims.

In Indonesia, women, men, and children are exploited for forced labor in the fishing, fish processing, construction sectors; in plantations, including oil palm plantations; and in mining and manufacturing.[15] Many women are exploited in the domestic sector and the sex trade. Victims are often recruited with the lure of a job offer in a restaurant, factory, or a domestic worker but is actually used as a commercial sex worker (CSW).[16]

Debt is very common for trafficking victims. Women and adolescent girls were used as prostitutes in mining operations in Maluku, Papua and Jambi provinces.[17] Child sex tourism is commonly found in the Riau Islands bordering Singapore, and Bali is also a destination for Indonesian tourists involved in child sex tourism.

Trafficking of children for the purpose of prostitution or some of the so-called prostituted children is one of the worst forms of child labor, this can be seen from the ILO Convention 182 which has been ratified by the Indonesian government as a law. Law No. 1 of 2000 on Ratification of ILO Convention 182 on the Prohibition and Immediate Action of the Elimination of the Worst Forms of Child Labor.[18]

The worst forms of child labor can be categorized as child slavery or similar to slavery such as child trafficking, childhood as security of debt or forced labor, the use or offer of a child for prostitution or for the production of pornography or pornographic performances, the use or offer of a child for the activity dark / forbidden especially for the production and sale of drugs, workplace or natural environment that endanger the health, safety and morals of children.

Addressing the issue of child trafficking, the Government of the Republic of Indonesia issued a policy in the field of criminal law to prevent and combat trafficking in persons including minors. This is followed by the issuance of Law Number 21 of 2007 on the Eradication of Crime of Trafficking in Persons and the Draft of the National Criminal Code where there are several articles regulating the crimes of trafficking in persons. This legal tool is a way to overcome the crime of trafficking of minors by implementing policies that include: Prevention, prosecution to traffickers, and protection measures against victims.[19]

In the National Coordination Meeting for the Crime of Human Trafficking (NCMCHT) of the Ministry of Women Empowerment and Child Protection , which took place on 28 August in Bali. Whether it's from self-help communities, academics, business world and mass media. Cooperation is needed to overcome the problems of people's trade from upstream. In this meeting also recommended some things for human trafficking.

The reported human traffficking data is very small compared to the actual data. Based on data obtained from the Ministry of Foreign Affairs from 2012 to May 2016, there are 1,223 human trafficking cases involving Indonesian citizens abroad. Therefore, the government is committed to ending human trafficking with the support of all relevant stakeholders and the community.

For this issue it is strongly recommended to increase efforts in investigating, prosecuting and punishing labor agencies, brokers and corrupt public officials involved in trafficking; develop and implement procedures to identify potential victims among vulnerable groups, including repatriation of migrant workers, prostitution workers, and fishing vessel crews. 
In addition, it also provides training for the Ministry of Marine Affairs and Fisherie staff and supervisors related to the identification of victims and referral procedures; conducting training for judges, prosecutors, police and social workers on anti-trafficking laws; take steps to eliminate recruitment fees imposed by labor suppliers to prospective workers; proactively provide identified victim reintegration services; promoting official and safe migration with efforts to prevent trafficking in persons; increase the human resources of anti-trafficking task force (co-tasks) and improve coordination among ministries; create a data collection system to track anti-trafficking efforts at all levels of law enforcement; train hospital staff and other healthcare providers in terms of ensuring government-funded care for victims of trafficking in persons; as well as creating a national protocol explaining the responsibility for prosecuting trafficking cases outside of the victim's home province.

The Ministry of Foreign Affairs assisted 478 victims of trafficking of persons from Indonesia abroad through their consulates and embassies; an increase of 413 victims in the previous reporting period. (Indonesia 2017) In 2016, the Ministry of Foreign Affairs sent 13,714 Indonesian citizens, and other governments deported 27,855 people, compared to 9,039 people discharged and 85,490 deported in 2015. Of these figures, the Ministry of Foreign Affairs identified 602 trafficking victims (compared to 541 victims of 2015) and assisted in the immediate repatriation of 460 victims, compared with 306 victims in 2015 . The Ministry of Foreign Affairs spent 240,398 US dollars to compensate victims, providing them temporary shelter and providing other services upon their return to Indonesia. Kemenlu also handed them over to local government institutions for further handling.

The government continues to rely on international organizations and NGOs in identifying victims-notably victims of foreign nationals in Indonesia-as well as efforts in complementing government-funded protection services. While endorsing the ILO Maritime Labor Convention in September and establishing protocols for the inspection of crew casualties in 2015, government institutions do not uniformly comply with both mechanisms during the reporting period.[20]

The government continues to work with NGOs in identifying trafficking victims among crews of ships secured or drowned as part of a 2014 moratorium on illegal fishing, but there is no data on the amount until the reporting period. Throughout the reporting period, the Government has initiated a new mechanism to improve the facilitation of victim protection services, but it does not say how often the government uses applications connecting users with the nearest Indonesian Ministry of Foreign Affairs and Embassy hotline and consulate abroad.

The renewal of the criminal law is an attempt to reform and reorient the criminal law in accordance with socio-political, socio-philosophical and socio-cultural values of society underlying criminal policies. The criminal law policy is part of the criminal policy. In the perspective of criminal policy, criminal law policy can be interpreted as crime prevention policy by using criminal law. Viewed from a political point of view, criminal law can be interpreted as a policy to realize better legislation in society to achieve what is desired.[21]

According Harkristuti Harkrisnowo there are several articles in the Criminal Code that can be used to capture some deeds of trafficking people although not out of various weaknesses. Article 297 of the Criminal Code specifically regulates the trafficking of women and boys under age. Seen from the angle of the corbann, almost all cases found victims are women and children under age, including infants.[22] 
Another problem relating to Article 297 of the Criminal Code is about the age limit of immature (under age) for trafficked boys. As is known, there is no single provision that explicitly gives the age limit of immature or adult age. In the articles that stipulate that the victim should be underage, there are also articles specifically mentioning the age of 12 years, 15 years, 17 years so there is no clear benchmark for this age problem.

Regarding this age limit there must be a strict stipulation that there is only one understanding. In addition to Article 297 of the Criminal Code, Article 324 can also be used to capture some of the trafficking of persons because this passage prohibits acts that can be categorized as human trafficking, but the object is specifically mentioned as a slave so that the validity of this article becomes very narrow. In addition to the Criminal Code, Act Number 23 of 2002 concerning Child Protection may also be used to encompass traffickers as provided for in Article 83 that any person who trades, sells or kidnap a child for himself or for sale is punished with a maximum imprisonment of 15 (fifteen) years and a short 3 (three) years and a fine of not more than $\mathrm{Rp} \mathrm{300,000,000} \mathrm{and} \mathrm{a} \mathrm{minimum} \mathrm{of} \mathrm{Rp} \mathrm{60,000,000.}$ but in this law, the scope is limited to children so that traffickers of persons who are not children are not subject to this law.

\section{Conclusions}

Human trafficking is an act of recruitment, transportation, shelter, transfer, transfer or acceptance of persons with threats of violence, the use of harassment, abduction, capture, falsification, fraud, abuse of power or vulnerable positions, debt bondage or paying or benefits, persons exercising control over such persons, whether committed within States or between States, for the purpose of exploitation or exploitation of persons. Similarly, child prostitution is not always a victim of trafficking, because to be categorized as a trafficking victim the child must be recruited by a network of syndicates, or the child is deceived with incorrect information about the work to be performed. Child trafficking may be for various purposes, including for prostitution, for pornographic objects, for forced labor, for organ transfusion, for drug traffickers, for adoption and so forth.

The renewal of the criminal law is an attempt to reform and reorient the criminal law in accordance with socio-political, socio-philosophical and socio-cultural values of society underlying criminal policies. The criminal law policy is part of the criminal policy. In the perspective of criminal policy, criminal law policy can be interpreted as crime prevention policy by using criminal law. Viewed from a political point of view, criminal law can be interpreted as a policy to realize better legislation in society to achieve what is desired. Several articles in the Criminal Code that can be used to capture some deeds of trafficking people although not out of various weaknesses. Article 297 of the Criminal Code specifically regulates the trafficking of women and boys under age. Seen from the angle of the corbann, almost all cases found victims are women and children under age, including infants. Relating to Article 297 of the Criminal Code is about the age limit of immature (under age) for trafficked boys. As is known, there is no single provision that explicitly gives the age limit of immature or adult age.

The presence and performance of the Task Force at both the provincial and local levels should be maximized, the need for special studies for all districts / municipalities in the case of trafficking in children, and the organization of productive economic enterprises should be evaluated because of the tendency of some inadequate targets and the possibility of creating programs - continued empowerment programs, and the importance of reregistration of trafficking cases recorded in relevant and strategic agencies such as the 
police, the Social Service, the Office of Manpower, and Non-Governmental Organizations in order that case handling can be more targeted.

\section{References}

1. H. Harkrisnowo, Laporan Perdagangan Manusia Di Indonesia. p. 69 (Universitas Indonesia, Jakarta, 2003)

2. F. Astrid, Pemberantasan Perdagangan Orang Dalam Surat Kabar Elektronik di Lima Negara Asean. Jurnal Komunikasi KAREBA, 3, p.3 (2011)

3. Farid, Kejahatan Seksual Terhadap Anak, Implementasi Konvensi Hak Anak Di Indonesia Dan Agenda Aksi dari Stockholm. p. 10 (Jakarta, 1997a)

4. Farid, Kejahatan Seksual Terhadap Anak, Implementasi Konvensi Hak Anak Di Indonesia Dan Agenda Aksi dari Stockholm. p. 10 (Jakarta, 1997b)

5. J. Collins, The Convention on The Rights of The Child: Is Thailand To Blame? Childen's Legal Rights Journal,35, p 85 (2015)

6. N. Fadilla, Upaya Perlindungan Hukum Terhadap Anak Sebagai Korban Tindak pidana Perdagangan Orang (The Legal Efforts of Child as a Criminal Victim in Human Trafficking). Jurnal Hukum dan Peradilan, 5, p. 181-194 (2016)

7. J. Weaner, The Cambodian Women's Crisis Center: Safety, Shelter, Training...And Then? McMaster School For Advancing Humanity, 7. p.7 (2008)

8. A. T. Wulang, J. Nawawi, \& Nurlimah. Analisis Penerapan Kebijakan Pencegahan dan Penghapusan Perdagangan Perempuan dan Anak di Kota Makasar, Government: Ilmu Pemerintahan, 6, p. 14 (2013)

9. A. Syamsuddin, Tindak pidana khusus, p. 193 (Anak Negeri Publisindo, Jakarta, 2014)

10. B. N. Arief, Beberapa Aspek Kebijakan Penegakan Dan Pengembangan Hukum Pidana, p. 156 (Kencana, Jakarta, 2008)

11. Arif Gosita, Masalah Korban Kejahatan, p. 18 (Bhuana Ilmu Poluler, Jakarta, 2004)

12. S. Agustina, Perdagangan Perempuan dan Anak Sebagai Kejahatan Transnasional, Jurnal Hukum Projustitia, 24, p. 48 (2006)

13. A. S. Nugroho, Bongkar Kasus Hukum Trafficking, Satgas Tindak Pidana Perdagangan Orang Polri Sudah Ciduk, Jakarta: Republik.co.id (2017)

14. R. A. Susilo, Kebijakan Perlindungan Hukum Bagi Anak Korban Trafficking, Peraturan Perundang-undangan Di Indonesia, 8, p. 6. (2016)

15. H. Handjani, R. Relawati, \& E. Handayanto, Gender Role In Traditional Fisherman Family and The Implication on Women Empowerment Model in Coastal Area of South Malang, Jurnal Perempuan dan Anak, 1 p. 21 (2015)

16. T. Marlina, Kajian Tentang Perlindungan Perempuan Korban Trafficking dalam Perspektif Kesehatan Jiwa, p. 18 (2012)

17. L. Rahman, E. Noerdin, E. Aripurnami. \& R. L. Yuningsih, Representasi Perempuan Dalam Kebijakan Publik Di Era Otonomi Daerah. Woman research Institute, 1, p. 43 (2005)

18. Y. M. Simarmata, Implementasi kebijakan Pelarangan dan Penghapusan BentukBentuk Pekerjaan terburuk Bagi Pekerja Anak di Kota Bandung. Fakultas Hukum universitas Atma Jaya, p. 11 (2015) 
19. S. Y. Ardianto, Perlindungan Hukum terhadap Anak Sebagai Korban Dari tindak Pidana Perdagangan Orang di Kota Pekanbaru. Jurnal Ilmu Hukum, 1, p. 4 (2016)

20. Y. Indriaswari, A. Prantiasih, \& R. A. Atok, The Role Of Integrated Pusat Pelayanan terpadu Pemberdayaan Perempuan dan Anak (PPTPPA) in Accompanying Child Abuse Victim in Malang regency, p. 4 (2017)

21. B. N. Arief, Bunga Rampai Kebijakan Hukum Pidana. P. 33 (Citra Aditya Bakti, Bandung, 1996)

22. H. Harkrisnowo, Laporan Perdagangan Manusia Di Indonesia, P. 56 (Universitas Indonesia, Jakarta, 2003) 